\title{
Politički i vojno-sigurnosni aspekt zbivanja u glinskoj općini 1990. - 1991. godine
}

\begin{abstract}
Rad nastoji odgovoriti na istraživačko pitanje kako je tekao razvoj prilika u Glini i okolici od povratka višestranačja 1990. do izbijanja lokalnih oružanih sukoba i pripajanja glinske općine Republici Srpskoj Krajini u prosincu 1991., promatrajući tamošnja zbivanja, s osobitim fokusom na hrvatsko-srpske međunacionalne odnose, na temelju političke i vojno-sigurnosne perspektive. Istraživanje se temelji na izvornom arhivskom gradivu srpske i hrvatske provenijencije, koje se čuva u Hrvatskom memorijalno-dokumentacijskom centru Domovinskog rata i Nadbiskupskom arhivu iz Zagreba te u Arhivu Policijske uprave sisačko-moslavačke u Sisku. Također su konzultirani sekundarni i tercijarni povijesni izvori o spomenutoj problematici, poput tiskovina koje su u razdoblju od 1991. do 1995. izlazile na prostoru pod nadzorom „krajinskih“" vlasti, u Republici Srbiji, kao i na teritoriju Republike Hrvatske pod kontrolom legalnih vlasti, ali i dostupnih monografija o zbivanjima u Hrvatskoj ranih 1990-ih. Tekst valja smatrati tek prilogom kompleksnijim istraživanjima Domovinskog rata na prostoru Banovine, koja će se, nadam se, poduzeti u bližoj budućnosti.
\end{abstract}

\section{Uvod}

Rad nastoji odgovoriti na istraživačko pitanje kako je tekao razvoj prilika u glinskoj općini od povratka višestranačja 1990. do izbijanja oružanih sukoba i proglašenja Republike Srpske Krajine (RSK) u prosincu 1991., promatrajući tamošnja zbivanja, s osobitim fokusom na hrvatsko-srpske međunacionalne odnose, na temelju političke i vojno-sigurnosne perspektive.

Istraživanje se temelji na izvornom arhivskom gradivu srpske i hrvatske provenijencije, koje se čuva u Hrvatskom memorijalno-dokumentacijskom centru Domovinskog rata i Nadbiskupskom arhivu iz Zagreba te u Arhivu Policijske uprave sisačko-moslavačke u Sisku. Također su konzultirani sekundarni i tercijarni povijesni izvori o spomenutoj problematici, poput tiskovina koje su u razdoblju od 1991. do 1995. izlazile na prostoru pod nadzorom krajinskih vlasti (Srpski glas, Bilten Ratnog predsjedništva i Štaba TO općine Glina), u Republici Srbiji (Politika, Borba, Narodna armija), kao i na teritoriju Republike Hrvatske pod kontrolom legalnih vlasti (Večernji list, Jedinstvo), ali i dostupnih monografija o zbivanjima u Hrvatskoj ranih 1990-ih, kako hrvatskih, tako i srpskih autora, koje se dijelom osvrću i na događaje u glinskom kraju. 
Važnost teksta ogleda se u činjenici kako se tematika vezana uz suvremenu povijest Općine Glina, unatoč svojoj općenitoj važnosti za razumijevanje uzroka i začetaka Domovinskog rata u cjelini, u hrvatskoj historiografiji dosad nije ozbiljnije istraživala. Rad, neovisno o tome, valja smatrati tek prilogom kompleksnijim istraživanjima Domovinskog rata na prostoru Banovine, koja će se, vjerujem, poduzeti u bližoj budućnosti.

\section{Razvoj političkih prilika u Općini Glina tijekom 1990. i 1991. godine}

\section{Od osnivanja prvih nacionalnih stranaka do pristupanja Srpskoj autonomnoj oblasti Krajina (SAO Krajina)}

Općina Glina, sukladno s podacima Državnog zavoda za statistiku Republike Hrvatske, 1991. imala je ukupno 23.040 stanovnika, od čega 13.975 Srba i 8.041 Hrvata, 62 Muslimana, kao i 473 žitelja koji su se izjasnili Jugoslavenima. Sama je općina imala 69 naseljenih mjesta, od kojih je 35, uključujući i grad Glinu, imalo srpsku, a 34 hrvatsku većinu stanovnika. ${ }^{1}$

Lokalni su Hrvati i Srbi, inače, imali povijest međusobnih trvenja, koja je sezala u dublju prošlost, a svoju je kulminaciju dosegnula u razdoblju Drugog svjetskog rata, kada je režim Nezavisne Države Hrvatske (NDH) počinio niz teških zločina nad banovinskim srpskim stanovništvom. Najveći broj tamošnjih Srba istovremeno je pristupio partizanskom pokretu, čiji su pripadnici tijekom, a posebice nakon okončanja rata provodili odmazdu nad mjesnim Hrvatima koji su bili pripadnici vojnih postrojbi NDH, ali i nad brojnim civilima, što su vlasti u poslijeratnom razdoblju, za razliku od ustaških zlodjela, prešućivale. ${ }^{2}$ Hrvatsko stanovništvo glinske općine, a poglavito oni Hrvati koji nisu bili sudionici Narodnooslobodilačke borbe (NOB) morali su se, štoviše, unatoč činjenici da je novoformirani jednopartijski socijalistički režim, nastojeći stvoriti novo, jedinstveno jugoslavensko društvo, na saveznoj razini javno propagirao politiku pomirbe, sadržanu u tada općeprihvaćenoj dogmi bratstva i jedinstva, te ih je, prema načelu nacionalnog ključa, uključivao u obnašanje lokalne vlasti, nositi s pokušajima nametanja osjećaja kolektivne odgovornosti za negativno nasljeđe NDH, dok su, s druge strane, lokalni Srbi (a osobito sudionici NOB-a), zahvaljujući vlastitoj moralno-političkoj podobnosti bili nesumnjivo privilegirani, zauzimajući ključne pozicije u partijskim i općinskim strukturama, kao i u mjesnoj policiji. ${ }^{3}$ Neuspjeh komunističke partije u definitivnom razrješavanju spomenutih

Vidi CRKVENČIĆ-BOJIĆ 1998: 1055-1089.

2 O istome vidi KRPAN 2007: 473-474; GAS̆LJEVIĆ TOMIĆ 2010: 484-513.

3 Prema podacima glinskog Općinskog komiteta Saveza komunista Hrvatske (SKH), u Općini Glina 1984. bilo je 1.685 članova SKH, od čega 74\% Srba (1.249), 19\% Hrvata (319), 6\% Jugoslavena (97) i 1\% ostalih (20), a članstvo u SKH bilo je preduvjet za sve politički, gospodarski i društveno utjecajnije pozicije. Vidi: Struktura članstva Općinske organizacije SKH, sekretara i sekretarijata. Bilten Općinske organizacije SKH Glina (Glina), svibanj 1984., 8. 
međunacionalnih prijepora rezultirao je time da su oni, nacionalnim gibanjem hrvatskog i srpskog naroda glinske općine krajem 1980-ih, ponovno izbili u javnost.

Kriza, koja se zbog pokušaja tadašnjeg vodstva Socijalističke Republike (SR) Srbije, na čelu sa Slobodanom Miloševićem, da s pomoću takozvanih antibirokratskih revolucija prigrabi vlast na federalnoj razini te potom uredi državu na unitarističkim načelima ${ }^{4}$, u međuvremenu raširila u Socijalističkoj Federativnoj Republici Jugoslaviji (SFRJ), s druge se strane, raspirivanjem nacionalizma i osjećaja ugroze među relativno brojnim hrvatskim Srbima, koje su, s ciljem destabilizacije Hrvatske, poticali mediji pod kontrolom režima u Beogradu, sve snažnije prezentirala i na nižim razinama vlasti, od čega, dakako, nije bila izuzeta ni glinska općina. ${ }^{5}$ Očita nemogućnost dotadašnjeg funkcioniranja Federacije, kao i sve evidentniji slom komunizma na međunarodnoj razini, naveli su republička rukovodstva SR Slovenije i SR Hrvatske da 1989. dopuste da se naredne, 1990., u tim republikama održe prvi višestranački izbori nakon Drugog svjetskog rata, pri čemu je u Hrvatskoj ubrzo došlo do osnivanja većeg broja političkih stranaka, koje su uglavnom imale nacionalne predznake i programe. ${ }^{6}$

I dok su novooformljene hrvatske stranke, poput Hrvatske demokratske stranke (HDS), čija je podružnica u Donjem Viduševcu u glinskoj općini utemeljena 1. ožujka 1990., te Hrvatske demokratske zajednice (HDZ), koja je 1. travnja osnovala ogranak u mjestu Gornja Bučica ${ }^{7}$, u vlastitim programima isticale težnju za hrvatskim samoodređenjem i suverenošću ${ }^{8}$, Srpska je demokratska stranka (SDS), osnovana 17. veljače 1990. u Kninu, u začetku ustrajavala na očuvanju federativnog načela unutarnjeg uređenja SFRJ. ${ }^{9}$ Opstanak su Federacije, nadalje, zagovarale i stranke poput Saveza komunista Hrvatske-Stranke demokratskih promjena (SKH-SDP), koju su činili reformirani komunisti, te Jugoslavenske samostalne demokratske stranke (JSDS), osnovane 11. veljače 1990. u Vojniću. ${ }^{10}$

Odbor SDS-a u Glini oformljen je 24. ožujka 1990. pred oko tisuću okupljenih pristaša na igralištu Nogometnog kluba „Banija“ te je za njegova prvog predsjednika izabran Petar Kralj. ${ }^{11}$ Predsjednik SDS-a Jovan Rašković tom je prigodom,

4 BARIĆ 2005: 29; GOLDSTEIN 2008: 625.

5 Vidi, primjerice: Ustaški bodež, malj i samokres. Narodna armija (Beograd), 2. VIII. 1990., 36-38.

6 BILANDŽIĆ 1999: 767; GOLDSTEIN 2008: 636; NAZOR 2007: 51.

7 GAŠLJEVIĆ TOMIĆ 2010: 533.

8 Vidi, primjerice: Što hoće HDZ i tko je i zašto napada?. Glasnik Hrvatske demokratske zajednice (Zagreb), siječanj 1990.

9 Hrvatski memorijalno-dokumentacijski centar Domovinskog rata, Srpska demokratska stranka, kut. 4, Programski ciljevi Srpske demokratske stranke, 17. veljače 1990.; GOLDSTEIN 2008: 659.

10 BARIĆ 2005: 56.

11 KNEŽEVIĆ 2011: 11. 
u govoru koji se uvelike temeljio na evociranju sjećanja na stradanja kordunskih i banovinskih Srba u Drugom svjetskom ratu, istaknuo kako hrvatski Srbi nikada neće dopustiti da se obnovi NDH i ponovi genocid nad njima te bi to morao biti i ,zajednički zadatak hrvatskog naroda i srpskog naroda u Hrvatskoj“. Govor je završio tvrdnjom kako srpskom narodu u Hrvatskoj „,ne trebaju niti malo-Srbi niti veliko-Srbi“, već mu trebaju „pametni Srbi, iskreni ljudi naoružani ljudskom dobrotom, bez oružja na rukama ili na ramenu“". ${ }^{12}$

Tijekom predizborne kampanje do izražaja je, očekivano, došla izrazita polariziranost odnosa lokalnog hrvatskog i srpskog stanovništva. Najveći je dio mjesnih Srba, za razliku od Hrvata, koji su uglavnom pružali podršku nacionalnim strankama ili su ostali posve politički pasivni, isprva podupirao SKH-SDP, smatrajući kako bi izborna pobjeda te stranke, kao izravne sljednice dotadašnjeg Saveza komunista, jamčila daljnje njegovanje tekovina NOB-a, u kojoj je ovdašnji srpski narod masovno sudjelovao i podnio velike žrtve, a na osnovi kojih mu je na 3. zasjedanju Zemaljskog antifašističkog vijeća narodnog oslobođenja Hrvatske (ZAVNOH), održanom u svibnju 1944. u Topuskom, zajamčena potpuna ravnopravnost s Hrvatima u novoj hrvatskoj federalnoj jedinici (velik je dio Srba u Hrvatskoj, dakako, za SKH-SDP glasovao i iz posve pragmatičnog razloga, vjerujući kako će eventualna pobjeda te stranke na izborima onemogućiti dolazak na vlast hrvatskih nacionalnih stranaka, a posebice HDZ-a). ${ }^{13}$

U prvom se krugu višestranačkih izbora u Glini, održanom tijekom druge polovine travnja 1990., istovremeno biralo odbornike u trima vijećima Sabora SR Hrvatske (Vijeće općina, Vijeće udruženog rada i Društveno-političko vijeće), kao i u trima vijećima Općine Glina. Lijeva je politička opcija, očekivano, odnijela apsolutnu pobjedu glede izbora za Vijeće općina Sabora SR Hrvatske, pri čemu je koalicija SKH-SDP-a i Socijalističke stranke Hrvatske (SSH) osvojila 67,8\%, a HDZ 29,7\% glasova birača. Rezultati prvog kruga izjašnjavanja za Društveno-političko vijeće Sabora SR Hrvatske bili su sljedeći: SKH-SDP i SSH osvojili su 54,9\%, SDS 17,1\%, HDZ 14,3\%, Koalicija narodnog sporazuma - KNS (koju su činile HDS, Hrvatska kršćansko-demokratska stranka - HKDS, Hrvatska socijalno-liberalna stranka-HSLS i Socijaldemokratska stranka Hrvatske-SDSH) 7,1\% i JSDS 3,7\% glasova. U drugome je krugu izbora za isto tijelo, početkom svibnja 1990., koalicija SKH-SDP-a i SSH dobila ukupno 59,6\%, HDZ 20,6\% te SDS $17,5 \%$ glasova. ${ }^{14}$

12 PASPALJ 1996: 46-49.

13 NOVAKOVIĆ 2009: 56.

14 GRDEŠIĆ, KASAPOVIĆ, ŠIBER I ZAKOŠEK 1991: 208-214; glede izbora za Društvenopolitičko vijeće Sabora SR Hrvatske, bitno je imati u vidu kako se Općina Glina, zajedno sa susjednim općinama Dvor i Kostajnica, nalazila u jednoj izbornoj jedinici (49. izborna jedinica sa sjedištem u Glini), stoga se navedeni rezultati ne odnose isključivo na tu općinu. Vidi Isto: 220-221. 
U spomenuta se vijeća Općine Glina, nadalje, biralo ukupno 84 odbornika, pri čemu je lijevi blok osvojio 52, SDS devet, HDZ sedam i KNS šest mandata, uz osam nezavisnih i dva nepopunjena odbornička mjesta. Što se njihove nacionalne pripadnosti tiče, radilo se o gotovo $73,17 \%$ osoba srpske te svega $26,83 \%$ osoba hrvatske nacionalnosti. ${ }^{15}$

Vlast u općini ostala je, dakle, neovisno o činjenici što je za predsjednika općinske Skupštine izabran Velibor Matijašević iz SDS-a ${ }^{16}$, čvrsto u rukama reformiranih komunista, što će u bližoj budućnosti, uslijed jačanja tamošnjih nacionalnih stranaka, dovesti do snažnih potresa na lokalnoj političkoj sceni. Na hrvatskoj je republičkoj razini, s druge strane, premoćnu pobjedu odnio HDZ, dok je SDS ostvario dobre rezultate u dijelu sjevernodalmatinskih i ličkih općina sa srpskom većinom, uz tendenciju daljnjeg rasta. ${ }^{17}$

Čelništvo SDS-a nedugo je potom, pod izlikom kako je izbornim trijumfom HDZ-a položaj hrvatskih Srba postao ,ugrožen“, od općina u kojima je ta stranka osvojila vlast (Knin, Gračac i Donji Lapac) ustrojilo Zajednicu općina sjeverne Dalmacije i Like, čime je zapravo učinjen prvi korak k izdvajanju tog teritorija iz hrvatskog ustavnopravnog poretka. ${ }^{18}$ Već 24 . srpnja 1990., na inicijativu devetorice glinskih odbornika SDS-a, koji su uspjeli zadobiti podršku 31 odbornika koalicije SKH-SDP-a i SSH srpske nacionalnosti u toj općini, usvojena je odluka o pristupanju Općine Glina navedenoj Zajednici. ${ }^{19}$ Idućeg je dana u ličkom mjestu Srb u organizaciji SDS-a održan Srpski sabor, na kojemu je izabrano Srpsko nacionalno vijeće (SNV), kao krovna politička institucija hrvatskih Srba, koje je odmah potom donijelo „Deklaraciju o suverenitetu i autonomiji srpskoga naroda" u Hrvatskoj. ${ }^{20}$

Kada je SNV 16. kolovoza 1990. odlučio da se na temelju gore spomenute Deklaracije, u razdoblju od 19. kolovoza do 2. rujna iste godine, u Hrvatskoj treba provesti referendum o autonomnom položaju njezinoga srpskog stanovništva, pripadnici hrvatskoga Ministarstva unutarnjih poslova (MUP), kako bi to spriječili, a ujedno i izvukli dio naoružanja rezervnog sastava policije iz policijskih postaja, čiji su djelatnici u međuvremenu iskazali protivljenje promjenama koje su provodile novoizabrane vlasti, već su narednog dana, 17. kolovoza, intervenirali u pojedinim sjevernodalmatinskim i ličkim općinama, na što su lokalni Srbi zaprekama

KRPAN 2007: 600.

16 GAŠLJEVIĆ TOMIĆ 2010: 533.

17 BARIĆ 2005: 61; KNEŽEVIĆ 2011: 18.

18 BARIĆ 2005: 66; RADULOVIĆ 1996: 17; PAUKOVIĆ 2005: 68-69.

19 Nadbiskupski arhiv Zagreb, Nadbiskupski duhovni stol, Glina 1955.-1995., kut. 3, uvez 4, Obavijest iz Gline Karla Lipaka o stanju u banijsko-kordunskoj regiji i Glini, upućena prečasnom gospodinu Josipu Klariću, Kaptol/Zagreb, 14. rujna 1990.; GAJDEK 2008: 49.

20 BARIĆ 2005: 72; GOLDSTEIN 2008: 665; RADULOVIĆ 1996: 18-19. 
blokirali tamošnje vitalne cestovne i željezničke komunikacije. ${ }^{21}$ Istovremeno je i stanje u Banovini postajalo sve složenije. U Glini je (kao i u Dvoru), naime, došlo do okupljanja više stotina građana ispred zgrade Skupštine općine, pri čemu je predsjednik mjesnog odbora SDS-a Petar Kralj, govoreći pred prosvjednicima, istaknuo kako će se „srpski narod oštro suprotstaviti ustaškim manirima nove vlasti“", što je naišlo na burno odobravanje prisutnih. ${ }^{22}$

Na teritoriju glinske općine nekoliko je dana potom, bez značajnijih incidenata, održano nelegalno izjašnjavanje, na kojemu se apsolutna većina lokalnih Srba opredijelila za srpsku autonomiju. ${ }^{23}$ Budući da su slični rezultati ostvareni i u preostalim hrvatskim općinama u kojima je živio znatan broj Srba (referendum je, osim toga, proveden i u Bosni i Hercegovini, Srbiji te u inozemstvu), SNV je 30. rujna 1990. proglasio autonomiju srpskog naroda u Hrvatskoj. ${ }^{24}$

Politička je situacija u Glini pak postajala sve kompleksnija. Pri tome su, svaka iz vlastitih pobuda, vlast koalicije SKH-SDP-a i SSH opstruirale i srpske (SDS) i hrvatske nacionalne stranke. Glinski je SDS, primjerice, 30. kolovoza 1990. lokalnoj općinskoj izbornoj komisiji predložio da opozove glinske zastupnike u Vijeću općina Sabora, Milivoja Vojnovića i Janka Vasiljevića (obojica srpske nacionalnosti), zato što ,slijede politiku SKH-SDP-a“, koju birači (radilo se o pretežno srpskom biračkom tijelu iz 30-ak mjesnih zajednica općine Glina) ocjenjuju kao „,izdajničku u odnosu na srpski narod u Hrvatskoj“ ${ }^{25}$ Stvari su, štoviše, otišle toliko daleko da su SDS i HDZ, svjesni raslojavanja u redovima lijeve koalicije, a vidjevši u tome mogućnost vlastitog političkog rasta, zajednički odbili podržati izbor općinskog Izvršnog vijeća, što je tijekom druge polovine 1990. dovelo do paralize funkcioniranja glinske općine. ${ }^{26}$ Kriza je u Hrvatskoj u međuvremenu uzimala maha. U Kninu je, naime, 21. prosinca 1990., nakon što je dio većinskih srpskih općina sjeverne Dalmacije, Like, Korduna i Banovine prihvatio njezin Statut, svečano proglašen osnutak SAO Krajine, kao oblika teritorijalne autonomije u sastavu Republike Hrvatske. ${ }^{27}$

21 RUNTIĆ 2003: 73-90; BOLJKOVAC 2009: 205; BARIĆ 2005: 79; GOLDSTEIN 2008: 666; RADULOVIĆ 1996: 20-21. 
Glinska je općinska Skupština, s druge strane, budući da ni šest mjeseci nakon provedenih izbora (što je bio nužan zakonski rok) nije formirano općinsko Izvršno vijeće, raspuštena te su raspisani novi izbori za općinske strukture vlasti, što je bio jedini takav slučaj u Hrvatskoj u tom razdoblju. Iz „Listâ kandidata za izbor odbornika u Vijeće mjesnih zajednica SO Glina“, koje je lokalno izborno povjerenstvo objavilo 25. siječnja 1991., vidljivo je kako su u većinskim srpskim mjestima glinske općine bile istaknute gotovo isključivo liste SDS-a, dok su u hrvatskim naseljima prevladavali kandidati HDZ-a i HDS-a. Hrvatske stranke, osim toga, uslijed činjenice da je u većini novooformljenih izbornih jedinica na području grada Gline prevladavalo srpsko stanovništvo (uz izuzetak izborne jedinice Jukinac, u kojoj su Hrvati činili većinu), ondje nisu istaknule vlastite kandidate, već su se na tamošnjim listama uglavnom nalazili kandidati SDS-a te simboličan broj nezavisnih, kao i kandidata Socijalističke partije Hrvatske-Partije jugoslavenske orijentacije (SPH-PJO), koju je tijekom kolovoza 1990. u Petrinji osnovao Borislav Mikelić. ${ }^{28}$ Zanimljivo je kako je vodstvo SKH-SDP-a, očito uvidjevši da su u općini nadvladale nacionalne stranke, u potpunosti odustalo od isticanja vlastitih lista za te izbore. Ovakva je odluka bez sumnje bila uvjetovana i time što je u razdoblju od održavanja višestranačkih izbora pa do kraja 1990. većina srpskih zastupnika SKH-SDP-a u glinskoj općinskoj Skupštini prešla u redove SDS-a, koji je na taj način na teritoriju općine izrazito osnažen. ${ }^{29}$

Novi općinski izbori provedeni su tijekom veljače 1991., pri čemu je birano ukupno 84 odbornika. SDS-u je, sukladno s rezultatima, pripala apsolutna vlast u općini ${ }^{30}$, uslijed čega je za novog predsjednika Skupštine općine izabran član te stranke, dr. Dušan Jović. ${ }^{31}$ U SDS-u je, inače, 16. ožujka 1991. došlo do raskola na republičkoj razini, kojom je prigodom zbog neslaganja dijela članstva, prema njihovu shvaćanju, s odveć suzdržanom politikom čelnika te stranke Jovana Raškovića glede rješavanja srpskog pitanja u Hrvatskoj, osnovana nova stranka, SDS Krajine, na čelu s Milanom Babićem. Čini se kako je novoj stranci, čija se politika temeljila na radikalnoj retorici, težeći beskompromisnom izdvajanju SAO Krajine iz sastava Republike Hrvatske i njezinu pripajanju srbijanskoj matici (odnosno ostanku u Jugoslaviji s ostalim republikama i pokrajinama koje su s tim bile suglasne), u kratkom vremenu pristupio i najveći dio glinskih SDS-ovaca. ${ }^{32}$

\footnotetext{
28 Hrvatski memorijalno-dokumentacijski centar Domovinskog rata, SO Glina, kut. 2, Izborna komisija SO Glina, Lista kandidata za izbor odbornika u Vijeće mjesnih zajednica SO Glina, 25. siječnja 1991.; u gradu Glini 1991. živjelo je ukupno 6.933 stanovnika, od kojih 4.831 Srba (gotovo 70\%), 1.448 Hrvata, 362 Jugoslavena i 292 ostalih, vidi CRKVENČIĆ-BOJIĆ 1998: 1068.

29 KRPAN 2007: 601; GAŠLJEVIĆ TOMIĆ 2010: 533.

30 KRPAN 2007: 601.

31 GAŠLJEVIĆ TOMIĆ 2010: 537.

32 BARIĆ 2005: 211-219.
} 
Istodobno su hrvatsko-srpski međunacionalni odnosi u Hrvatskoj ulazili u novu fazu napetosti. Početkom ožujka 1991. u Pakracu je, naime, došlo do prvog oružanog sukoba između lokalnih Srba i pripadnika MUP-a Republike Hrvatske, da bi na katolički Uskrs, 31. ožujka iste godine, pri pokušaju hrvatske specijalne policije u istjeravanju jedinica Milicije Krajine s područja Nacionalnog parka „Plitvička Jezera“", izbio novi sukob, pri čemu su pale i prve žrtve na objema stranama. ${ }^{33}$

Zastupnici glinske općinske Skupštine (bez hrvatskih odbornika, koji nisu bili pozvani na zasjedanje) istoga su dana na izvanrednoj sjednici usvojili odluku o izdvajanju Općine Glina iz sastava Republike Hrvatske i njezinu pristupanju SAO Krajini, kao i odluku o izdvajanju glinske policijske postaje iz sastava hrvatskog MUP-a i njezinu pripajanju Sekretarijatu unutrašnjih poslova (SUP) SAO Krajine (koji je osnovan početkom siječnja 1991.), odluku o izdvajanju „Šumarije Glina“ iz sastava Javnog poduzeća „Hrvatske šume“ te odluku o uvođenju srpskog jezika u službenu upotrebu u Glini. ${ }^{34}$ Time je ovdašnji međunacionalni sukob, bez sumnje, dodatno usmjeren k ratnom raspletu, koji će punom silinom uslijediti već u ljeto 1991.

\section{Od pripajanja SAO Krajini do ulaska u sastav RSK}

Odgovor hrvatske strane na spomenuta je zbivanja, očekivano, ubrzo uslijedio. Već 1. travnja 1991. odbornici Skupštine Općine Glina hrvatske nacionalnosti na sjednici u Gornjem Viduševcu obznanili su formiranje Zajednice hrvatskih mjesnih zajednica Općine Glina. Istovremeno su sve odluke ,jednostranačke i jednonacionalne" glinske općinske Skupštine proglašene nevrijedećima na području Zajednice te je naglašeno kako na njezinu teritoriju vrijede isključivo hrvatski zakoni. Osim toga, odlučeno je i kako će se, do daljnjega, nedolascima opstruirati sjednice lokalne Skupštine općine. ${ }^{35}$

Izvršno je vijeće SAO Krajine, s druge strane, istoga dana na zasjedanju u Titovoj Korenici donijelo odluku o ,prisajedinjenju“ SAO Krajine Republici Srbiji, što je i potvrđeno 12. svibnja 1991. na referendumu organiziranom u tu svrhu. ${ }^{36}$ U glinskoj općini tom je prigodom od ukupno upisanih 19.007 birača glasovalo njih 12.141 ili 64\%, pri čemu se za ,prisajedinjenje“ Srbiji, odnosno ostanak u Jugoslaviji izjasnilo 12.128 osoba, dok je protiv bilo svega njih osmero. ${ }^{37}$ Nekoliko je dana potom, 19. svibnja 1991., na teritoriju Republike Hrvatske održan

\footnotetext{
33 Isto: 114-117.

34 Isto: 97; KRPAN 2007: 601; Glina se otcepila od Hrvatske. Politika (Beograd), 2. IV. 1991., 7.

35 KRPAN 2007: 602; GAŠLJEVIĆ TOMIĆ 2010: 537-538.

36 BARIĆ 2005: 101-102; Jednoglasno za pripajanje Srbiji. Borba (Beograd), 17. V. 1991., 8; Doneta odluka o prisajedinjenju Krajine Republici Srbiji. Politika (Beograd), 17. V. 1991., 9.

37 RUPIĆ 2007b: 172-177.
} 
referendum o hrvatskoj samostalnosti, na kojemu se apsolutna većina stanovništva založila za napuštanje SFRJ, odnosno za neovisnost Republike Hrvatske. Hrvati glinske općine s oduševljenjem su poduprli izjašnjavanje, dok su ga mjesni Srbi, očekivano, bojkotirali. ${ }^{38}$

Kada je Hrvatski sabor, sukladno s rezultatima svibanjskog referenduma, 25. lipnja 1991. donio Ustavnu odluku o samostalnosti i suverenosti Republike Hrvatske $^{39}$, sigurnosna se situacija na teritoriju Općine Glina uvelike pogoršala. Predsjednik općine dr. Jović smjesta je, na sjednici općinskog Ratnog predsjedništva, proglasio ratno stanje, koje je trebalo biti na snazi sve dok hrvatske snage ne budu ,izbačene“ s područja SAO Krajine, odnosno s teritorija općine („Odluka o proglašenju ratnog stanja“" službeno je usvojena nekoliko dana potom, odnosno 1. srpnja 1991.). ${ }^{40}$

Štoviše, u organizaciji glinskog općinskog rukovodstva već je idućeg dana izvršen napad srpskih pobunjenika na mjesnu policijsku postaju, u kojoj su se nalazili hrvatski policajci (vojni aspekt sukoba u Glini i glinskoj općini bit će detaljno obrađen u idućem poglavlju). Nakon intervencije hrvatske specijalne policije, napadači su se dali u bijeg, no u grad je uskoro pristigla oklopna jedinica Jugoslavenske narodne armije (JNA), koja je ondje formirala „tampon-zonu“. Pripadnici MUP-a Republike Hrvatske uspjeli su pritom ponovno preuzeti nadzor nad policijskom postajom, čime je u gradu uspostavljen svojevrstan status quo, koji će potrajati sve do 27. srpnja 1991. i konačnog povlačenja hrvatskih snaga iz Gline. ${ }^{41}$

Političko se djelovanje u glinskoj općini u narednom razdoblju (a osobito nakon što je početkom listopada 1991. cijeli prijeratni teritorij te općine dospio pod srpsku kontrolu) svelo gotovo isključivo na aktivnosti SDS-a Krajine, koji je preko općinskog Ratnog predsjedništva širio otvorenu ratnu retoriku, s posebnim naglaskom na nemogućnosti ikakvog budućeg suživota s Hrvatima. Tako je, primjerice, dr. Jović u razgovoru za list Srpski glas iz Topuskog istaknuo kako je

38 KRPAN 2007: 602.

39 BARIĆ 2005: 119; GOLDSTEIN 2008: 694; MATKOVIĆ 2006: 563; Jugoslavija pred raspadom. Borba (Beograd), 26. VI. 1991., 1.

40 KRPAN 2007: 602; GAJDEK 2008: 99; Situacija na Baniji sve teža. Politika (Beograd), 26. VI. 1991., 5; Proglašen prvi stepen pripravnosti. Politika (Beograd), 26. VI. 1991., 6; Odluka o proglašenju ratnog stanja, SFRJ, SAO Krajina, SO Glina, Ratno predsjedništvo, klasa: 80302/91-01/02, urbr.: 2124-01-01/01-2. Bilten Ratnog predsjedništva i Štaba TO općine Glina (Glina), 1. srpnja 1991., 7.

41 Hrvatski memorijalno-dokumentacijski centar Domovinskog rata, Neraspoređeno gradivo, Komanda 622. mtbr., Obaveštajni organ, strogo poverljivo br. 26/352-1, 26. lipnja 1991.; BARIĆ 2005: 120; KRPAN 2007: 602; GAJDEK 2008: 100; MARIJAN 2008: 263; TARBUK 2009: 135-137; Dva mrtva, 13 ranjenih. Borba (Beograd), 27. VI. 1991., 3; Narod u zbegovima, specijalci se koncentrišu oko naselja. Politika (Beograd), 28. VI 1991., 9. 
srpski narod u Hrvatskoj teško pogriješio što je u poslijeratnom periodu omogućio ponovno dovođenje „,ustaških koljača i dželata na politički tron“, davši im „,nnagu i mogućnost da iskolaboriraju sa Austrijom i Njemačkom ponovo program najvećih protivnika jugoslavenske države i srpskog naroda“. Tom prigodom zaključio je kako je ,jedino ispravno rješenje“ da srpski narod u Hrvatskoj „konačno živi u jedinstvenoj državi sa Srbijancima, Crnogorcima i drugim narodima...u okviru jedinstvene Jugoslavije“. ${ }^{42}$

Glini je, s druge strane, prema planovima srpskog vodstva iz Knina, među čijim se pripadnicima isticao i prvi predsjednik Skupštine SAO Krajine (a ujedno i bivši predsjednik glinske općinske Skupštine), Glinjanin Velibor Matijašević (kojega je u studenom 1991. zamijenio sugrađanin Mile Paspalj), namijenjena uloga svojevrsnog središta Banovine te su se ondje ubrzo stale ustrojavati pojedine značajnije institucije vlasti SAO Krajine. Na sjednici Vlade SAO Krajine, održanoj 16. listopada 1991. u Kninu, tako je usvojen „Zakon o teritorijalnoj nadležnosti i sjedištima okružnih i opštinskih sudova SAO Krajine“, sukladno s kojim je u Glini osnovan okružni sud, koji je trebao biti nadležan za područje općinskih sudova u Vojniću, Vrginmostu, Dvoru, Glini, Kostajnici, Okučanima i Petrinji. Istodobno je, ,Zakonom o teritorijalnoj nadležnosti i sjedištima okružnih i opštinskih javnih tužilaštva“, ustrojeno i glinsko okružno javno tužiteljstvo, nadležno za rad javnih tužiteljstava na teritoriju Korduna i Banovine. Vlada je SAO Krajine, nadalje, na istom zasjedanju donijela i „Odluku o dislociranju dijela poslova ministarstva u opštinu Glina“" koja u konačnici nije provedena u djelo. ${ }^{43}$

Situacija u općini, koja se i prije rata smatrala nerazvijenom, uz dvostruko niži dohodak po glavi stanovnika od hrvatskog prosjeka te vrlo visok postotak nezaposlenosti ${ }^{44}$, tijekom druge polovine 1991., neovisno o poduzetim pokušajima njezine konsolidacije, bila je veoma loša. Ratni su sukobi, naime, doveli do znatnih migracija lokalnog stanovništva, pri čemu su tamošnji Hrvati najvećim dijelom napustili vlastite domove i otišli u progonstvo, dok je u Glinu, s druge strane, pristigao velik broj Srba, koji su izbjegli s područja pod kontrolom legalnih hrvatskih vlasti. ${ }^{45}$ Mjesno se gospodarstvo, nadalje, uslijed gubitka dotadašnjih tržišta, sirovina i kroničnog nedostatka električne energije i radne snage, koja je bila mobilizirana, naprosto urušilo. ${ }^{46}$ Najveći

42 Predsjednik koji je ostao sa svojim narodom. Bilten Ratnog predsjedništva i Štaba TO općine Glina (Glina), 11. XI. 1991., 5-7 (intervju prenesen iz lista Srpski glas). 
broj radno sposobnog stanovništva, sukladno s time, nije primao (ili je primao posve simbolične) osobne dohotke, dok su lokalni umirovljenici, kojih je prema procjenama općinske Skupštine krajem 1991. bilo preko 2.300, jedva preživljavali, budući da su im hrvatske vlasti još u svibnju iste godine, nakon odluke glinskog općinskog rukovodstva o pristupanju SAO Krajini, obustavile isplatu mirovina. ${ }^{47}$ Mjesno se zdravstvo pak borilo s osipanjem stručnih kadrova, kao i manjkom lijekova, dok je slično stanje, uslijed velikog broja novopridošle, izbjegle djece, koju je valjalo uklopiti u postojeći sustav, nedostatka školskog osoblja i materijala te ratne opasnosti, zbog koje se u više navrata odgađao početak nove školske godine, bilo i u tamošnjim obrazovnim ustanovama. ${ }^{48}$ Sve navedeno pogodovalo je porastu osjećaja besperspektivnosti i beznađa među stanovništvom općine, kao i snažnoj kriminalizaciji lokalnog društva. U takvim je okolnostima, u sklopu SAO Krajine, Općina Glina 19. prosinca 1991. postala dio novoosnovane $\mathrm{RSK}^{49}$

\section{Vojno-sigurnosna situacija u Glini i okolici 1990. i 1991. godine}

\section{Začeci i razvoj oružanih sukoba u glinskoj općini}

Rezultati višestranačkih izbora 1990. pridonijeli su porastu napetosti između hrvatskog i srpskog stanovništva Banovine, koja je dodatno potencirana izbijanjem „balvan-revolucije“ i pojavom prvih srpskih barikada na tamošnjim prometnicama. ${ }^{50}$ Ubrzo nakon smirivanja stanja, već 28 . rujna 1990. došlo je do nove krize, koja je zaprijetila prerastanjem u otvorene oružane sukobe. Toga je dana, naime, pri pokušaju hrvatske policije da izvuče pričuvno naoružanje policije iz postaja u Petrinji, Glini i Dvoru, ondje, u organizaciji lokalnih odbora SDS-a, došlo do masovnog okupljanja srpskog stanovništva. Pri tome je najteža situacija, bez sumnje, bila upravo u Petrinji, gdje su u razbijanju srpskih demonstracija sudjelovale i specijalne postrojbe hrvatske policije. U centru se Gline istovremeno okupilo oko 1.200 ljudi, koji su, uslijed vlastite brojnosti i relativno malog broja lokalnih policajaca (od kojih je dio, srpske nacionalnosti, surađivao s prosvjednicima), uspjeli

47 Tamošnjim su se umirovljenicima, počevši od sredine listopada 1991., mirovine isplaćivale preko Republičkog fonda za penziono-invalidsko osiguranje Republike Srbije, vidi: Uskraćeno pravo penzionerima. Bilten Ratnog predsjedništva i Staba TO općine Glina (Glina), br. 3, 7. X. 1991., 33-34.

48 Kada će škole početi s radom?. Bilten Ratnog predsjedništva i Štaba TO općine Glina (Glina), br. 4, 11. XI. 1991., 37-38; o problemima zdravstva vidi: Medicinski centar u ratnim uvjetima. Bilten Ratnog predsjedništva i Štaba TO općine Glina (Glina), br. 2, 10. IX. 1991., 28-29. BARIĆ 2005: 146; DAKIĆ 1994: 57; NOVAKOVIĆ 2009: 182; PETROVIĆ 1996: 199; ŽUNEC 2007: 275; Nova republika - Srpska Krajina. Borba (Beograd), 20. prosinca 1991., 5.

50 Prve zapreke na prostoru Banovine pojavile su se 24. kolovoza 1990. na cesti Petrinja - Jabukovac, u predjelu zvanom Tješnjak, kao i na lokalitetu Jeginovac, vidi GAJDEK 2008: 55. 
oteti oružje iz tamošnje policijske postaje i odnijeti ga u nepoznatom pravcu. Isto se dogodilo i s većim dijelom naoružanja u susjednom Dvoru. ${ }^{51}$ Hrvatske su vlasti ubrzo potom, pravdajući taj čin manjkom otpora srpskim demonstrantima i odbijanjem provođenja zapovijedi, smijenile i uhitile policijske načelnike u Petrinji i Glini, Ljubana Lončarevića i Milu Divjakinju ${ }^{52}$, a u glinsku je postaju početkom listopada 1990. pristigao dio novih policajaca hrvatske nacionalnosti. ${ }^{53}$ Policijska je uprava Sisak, štoviše, u idućim mjesecima u Glinu poslala trojicu inspektora sa zadaćom da uđu u trag otetom policijskom naoružanju. ${ }^{54}$ Do kraja godine manji je dio oružja (dvije strojnice od sedam otetih, 11 pištolja od 77 otetih i 14 pušaka) i streljiva pronađen kod nekolicine civilnih osoba na području glinske općine i vraćen policiji ${ }^{55}$, a potraga je nastavljena i sljedeće, 1991. Hrvatsko je vodstvo, kao odgovor na ta zbivanja, dopustilo da se, s ciljem njihove nužne zaštite, naoruža i dio mjesnih Hrvata, što je uglavnom učinjeno u organizaciji tamošnjih ogranaka HDZ-a (u slučaju Općine Petrinja radilo se, primjerice, o 100-tinjak komada automatskog oružja). ${ }^{56}$

O razini međusobnog nepovjerenja lokalnih Hrvata i Srba tijekom druge polovine 1990. svjedoči i dokument obavještajnog organa Komande 5. vojne oblasti JNA od 3. listopada iste godine. U njemu se, naime, armijsko rukovodstvo izvješćuje kako je veći dio muškog stanovništva srpske nacionalnosti iz sela Obljaj, Šaševa i Majske Poljane na području tadašnje glinske općine, u strahu od Hrvata iz okolnih naselja i pripadnika hrvatske policije, napustio vlastite domove i povukao se u šumu s oružjem. Također se navodi i kako pojedini aktivisti SDS-a zagovaraju da se, u slučaju upada hrvatskih specijalaca u Glinu, izvrši napad na koje od susjednih hrvatskih naselja. ${ }^{57}$ Sigurnosno stanje na području Banovine 1991. dodatno se pogoršalo. Stanovništvo se, posebice nakon sukoba na Plitvi-

51 BARIĆ 2005: 83; GAJDEK 2008: 60-61; TARBUK 2009: 122-126.

52 Spriječeni nezakoniti postupci. Večernji list (Zagreb), 29. IX. 1990., 4-5; Teroriste čeka kazna. Večernji list (Zagreb), 30. IX. 1990., 4.

53 Arhiv Policijske uprave Sisačko-moslavačke, RH, MUP, PU Sisak, Sistematizacija, Pregled sistematiziranih radnih mjesta i popunjenost istih u policijskoj stanici Glina, 1. listopada 1990.

54 Hrvatski memorijalno-dokumentacijski centar Domovinskog rata, Neraspoređeno gradivo, kut. 1071/1, RSK, MUP, SUP Glina, br. 08-04/2-K-82/94., Službena zabilješka sastavljena dana 08. 09. 1994. godine u prostorijama SM Glina od strane ovl. Kraguljac Sime u vezi rada i postupanja Stojana Stojića, zapovjednika Policijske stanice Glina u vrijeme prije rata, 12. rujna 1994.; postoji realna mogućnost da su se srpski pobunjenici koristili dijelom spomenutog oružja prilikom napada na glinsku policijsku postaju 26. lipnja 1991., no to je, uslijed nedostatka izvora, veoma teško pouzdano ustvrditi.

55 Arhiv Policijske uprave Sisačko-moslavačke, Godišnje izvješće PU Sisak za 1990. godinu, br. 511-10-01/05-SP-36/1/91. SKU, 23. siječnja 1991. 
cama, uglavnom držalo vlastitih domova, izbjegavajući odlazak u polja i šume, a prethodna je komunikacija između pojedinih većinskih hrvatskih i srpskih naselja gotovo posve zamrla. ${ }^{58}$

Početkom 1991. vodstvo Policijske uprave Sisak za vršitelja dužnosti načelnika policijske postaje u Glini postavilo je inspektora Stojana Stojića, srpske nacionalnosti, koji je, do vlastite smjene u svibnju 1991. (zamijenio ga je Ivan Kvakić), djelovao u skladu s hrvatskim zakonima, nastojeći primiriti sve napetiju situaciju u općini. ${ }^{59}$ Čelnicima glinskih Srba, s druge je strane, osobito smetalo to što se zbog tamošnje prisutnosti hrvatske policije Odluka Skupštine Općine Glina o pripajanju glinske policijske postaje SUP-u SAO Krajine od 31. ožujka 1991. nije mogla provesti u djelo, što je pak ugrožavalo njihovu vlast u gradu i općini te im remetilo buduće planove.

Proglašenje hrvatske samostalnosti 25. lipnja 1991. stoga im je poslužilo kao dobrodošao povod da već narednog dana, 26. lipnja 1991., pokrenu napad na hrvatske policajce u Glini. Toga je jutra, naime, najmanje 150-ak naoružanih Srba, među kojima se, uz 70-ak civila iz Gline i 30-ak civila iz okolnih srpskih sela, nalazilo i 50-ak pripadnika Milicije SAO Krajine s područja Banovine (,Martićevci“), koji su tijekom proljeća 1991. prošli specijalnu obuku u sjevernodalmatinskom mjestu Golubiću kod Knina, napalo lokalnu policijsku postaju, koju je branio skroman broj policajaca. Tom je prilikom poginuo pričuvni policajac Tomislav Rom iz Donjeg Viduševca, kao prva hrvatska žrtva Domovinskog rata na ovom prostoru. Sama je postaja nakon višesatnog okršaja zauzeta te su hrvatski policajci zarobljeni i odvedeni u Knin, dok su na ulazu u Glinu iz pravca Jukinca i Donjeg Viduševca postavljene srpske barikade. ${ }^{60}$ Predsjednik glinske općine dr. Jović, u očitom strahu od očekivanog hrvatskog protuudara, smjesta je uputio apel Komandi garnizona JNA u Petrinji, tražeći njihovu pomoć, nakon čega je u Glinu upućena armijska oklopna jedinica. Iz pravca Siska u međuvremenu su pristigli pripadnici hrvatske specijalne policije (Antiteroristička jedinica Lučko), koji su, nakon kratkog okršaja u kojemu su poginuli „Martićevac“ Dragiša Stefanović i dvojica civila, natjerali pobunjene Srbe u bijeg. Ubrzo je potom u grad ušla i jedinica JNA iz Petrinje, čiju su prisutnost iskoristili hrvatski specijalci, kako bi se probili do napuštene policijske postaje i ponovno uspostavili nadzor nad njom. Tenkovi JNA tada su se

\footnotetext{
$58 \quad$ KRPAN 2007: 620.

59 Hrvatski memorijalno-dokumentacijski centar Domovinskog rata, Neraspoređeno gradivo, kut. 1071/1, RSK, MUP, SUP Glina, br. 08-04/2-K-82/94., Službena zabilješka sastavljena dana 08. 09. 1994. godine u prostorijama SM Glina od strane ovl. Kraguljac Sime u vezi rada i postupanja Stojana Stojića, zapovjednika Policijske stanice Glina u vrijeme prije rata, 12. rujna 1994.

60 Hrvatski memorijalno-dokumentacijski centar Domovinskog rata, Neraspoređeno gradivo, Komanda 622. mtbr., Obaveštajni organ, strogo poverljivo, br. 26/352-1, 26. lipnja 1991.; BARIĆ 2005: 120; GAJDEK 2008: 100; MARIJAN 2008: 263; TARBUK 2009: 135-137; Dva mrtva, 13 ranjenih. Borba (Beograd), 27. VI. 1991., 3.
} 
rasporedili u glinskom središnjem parku, izoliravši na taj način hrvatske policajce u postaji od ostatka grada, čime su srpskim napadačima omogućili da se s obližnjeg brda Pogledić, kamo su se sklonili prilikom intervencije hrvatske policije, vrate u Glinu i de facto preuzmu kontrolu nad većim dijelom mjesta. ${ }^{61}$

U zgradi Skupštine općine (koja se nalazila u neposrednoj blizini policijske postaje) nedugo potom održan je sastanak pomoćnika ministra unutarnjih poslova Republike Hrvatske Joška Morića i načelnika Policijske uprave Sisak Đure Brodarca s dr. Jovićem i zapovjednikom petrinjskog garnizona JNA potpukovnikom Đorđem Stojanovićem, tijekom kojega je Jović zatražio da pripadnici hrvatske policije napuste teritorij glinske općine, budući da se radi o području SAO Krajine, na kojemu ne vrijede zakoni Republike Hrvatske, nudeći zauzvrat puštanje zarobljenih glinskih policajaca. ${ }^{62}$

Glina je idućih dana, prema pisanju dopisnika beogradskih listova Politike i Borbe, bila nalik na „avetinjsko“ mjesto, pri čemu je centar grada bio potpuno pust, dok su na ulicama još bili vidljivi tragovi krvi. Snage su JNA, uz središte, kontrolirale i ključne prometnice oko naselja. Postrojbe hrvatske policije i Zbora narodne garde (ZNG) s druge su strane nadzirale ulaz u grad iz pravca Jukinca, a u samom su se gradu utvrdile u uskom pojasu između policijske postaje i rijeke Gline. ${ }^{63}$

Ratno predsjedništvo općine ubrzo je pozvalo „sve građane Banije, Korduna, Like i cijele Krajine i svih dijelova Jugoslavije koji vole i žele Jugoslaviju i jedinstvenu JNA, neka se uključe u zajedničku borbu sa Krajinom protiv hrvatskog vrhovništva i njegove politike“ . ${ }^{64}$ Već 1 . srpnja 1991. donesena je „Odluka o mobilizaciji Štaba i jedinica TO opštine Glina“65 , da bi 11. srpnja 1991. Vlada SAO Krajine imenovala dr. Jovića zapovjednikom Regionalnog štaba Teritorijalne obrane (TO) za područje općina Vojnić, Glina, Dvor, Kostajnica, Petrinja i Sisak. ${ }^{66}$ U Glini

${ }_{61}$ Hrvatski memorijalno-dokumentacijski centar Domovinskog rata, Neraspoređeno gradivo, Komanda 622. mtbr., Obaveštajni organ, strogo poverljivo, br. 26/352-1, 26. lipnja 1991.; Između dve vatre. Narodna armija (Beograd), 6. VII. 1991., 46; Banija na pragu rata. Narodna armija (Beograd), 17. VII. 1991., 8. GAJDEK 2008: 101; Narod u zbegovima, specijalci se koncentrišu oko naselja. Politika (Beograd), 28. VI. 1991., 9.

63 Noćna pucnjava od Dvora na Uni do Kostajnice. Politika (Beograd), 2. VII. 1991., 8; Opet sukob oko stanice milicije. Politika (Beograd), 3. VII. 1991., 13; Glina-mrtav grad. Borba (Beograd), 29./30. VI. 1991., 7.

64 Proglas Ratnog predsjedništva Skupštine općine Glina. Bilten Ratnog predsjedništva i Štaba TO općine Glina (Glina), srpanj - kolovoz 1991., 2.

65 Odluka o mobilizaciji Štaba i jedinica TO opštine Glina, SFRJ, SAO Krajina, SO Glina, Ratno predsjedništvo, klasa: 803-02/91-01/03, urbr. 2124-01-01/01-1. Bilten Ratnog predsjedništva $i$ Štaba TO općine Glina (Glina), 1. VII. 1991., 8.

66 Hrvatski memorijalno-dokumentacijski centar Domovinskog rata, fond 4, Vlada SAO Krajine/ RSK, kut. 1, Rješenje o imenovanju komandanta Regionalnog štaba TO za područje opština Vojnić, Glina, Dvor, Kostajnica, Petrinja i Sisak, br. 143/91-3, 11. srpnja 1991. 
je, nadalje, započet rad na ustrojavanju 1. glinske brigade TO, koja će naknadno dobiti ime po poginulom pobunjeniku Dragiši Stefanoviću. ${ }^{67}$

Glinski su ,teritorijalci“ 16. srpnja izveli i prvi minobacački napad na hrvatsko naselje Gornji Viduševac, u kojemu su se, posebice nakon 26. lipnja 1991., smjestile snage ZNG-a i hrvatske policije, pri čemu je ondje poginuo gardist Željko Putar-Grdak. ${ }^{6}{ }^{8}$ Spomenuta su zbivanja predstavljala svojevrstan uvod u konačan obračun s hrvatskim policajcima i gardistima u Glini, u ostvarenju kojega su, osim lokalnih Srba, trebali sudjelovati i pripadnici jedinice za specijalne namjene SUP-a SAO Krajine pristigli iz Knina, kojima je rukovodio Dragan Vasiljković, poznatiji kao „kapetan Dragan“. Tako je do ponovnog, općeg napada na glinsku policijsku postaju došlo 26. srpnja 1991. Srpski su napadači pritom, namjernim otvaranjem vatre po tenkovima JNA, pokušali isprovocirati Armiju da također napadne hrvatske položaje, što im je ubrzo i pošlo za rukom. Pripadnici MUP-a Republike Hrvatske i ZNG-a pružali su žestok otpor te su, tek nakon što je zaprijetila opasnost da budu posve odsječeni, pregazili rijeku Glinu i izvukli se prema obližnjem Donjem Viduševcu. Srpske su snage na taj način 27. srpnja ušle u napuštenu zgradu glinske policije, osvojivši ujedno i predgrađe Jukinac na sjeveroistočnom ulazu u grad. ${ }^{69}$

Hrvatske su postrojbe, s druge strane, nakon okupacije Gline uspostavile sjevernu liniju obrane istoimene općine u hrvatskim selima Novo Selo Glinsko, Marinbrod, Kihalac, Prekopa, Hađer, Dvorište, Donji i Gornji Viduševac te Šatornja. ${ }^{70}$ One su također kontrolirale i obližnje Topusko te Petrinju i Hrvatsku Kostajnicu. Jedinice su JNA, međutim, već 2 . rujna 1991. pokrenule prvi, neuspješan napad na Petrinju, da bi je 21. rujna konačno zauzele. ${ }^{71}$ Tijekom istoga mjeseca u srpske su ruke pali i Hrvatska Kostajnica te Topusko. ${ }^{72}$

Pobunjeni Srbi i JNA ${ }^{73}$ krajem rujna 1991. poduzeli su snažan napad na hrvatska uporišta Donji i Gornji Viduševac u glinskoj općini, natjeravši tamošnje

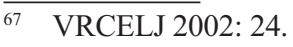

GAŠLJEVIĆ TOMIĆ 2010: 539.

GAJDEK 2008: 321; MARIJAN 2008: 272-273; TARBUK 2009: 144-145; GAŠLJEVIĆ TOMIĆ 2010: 539; Laži zbog nemoći i neuspjeha. Narodna armija (Beograd), 3. VIII. 1991., 17; Banija u crnim maramama. Borba (Beograd), 29. VII. 1991., 5; Branioci Gline potiskuju mupovce. Politika (Beograd), 27. VII. 1991., 1; Početak kraja okupacije Gline. Politika (Beograd), 28. VII. 1991., 8.

70 KRPAN 2007: 602.

71 GAJDEK 2008: 163; TARBUK 2009: 173-178.

72 GAJDEK 2008: 181-185; MARIJAN 2008: 277; Kostajnica bez gardista. Politika (Beograd), 14. IX. 1991., 1; Srpske snage ušle u Topusko. Borba (Beograd), 17. IX. 1991., 3.

73 Udarnu snagu JNA na teritoriju Banovine u tom su trenutku činile postrojbe 622. motorizirane brigade iz Petrinje i 544. motorizirane brigade iz Šapca, uz koje valja spomenuti i dijelove 51. mehanizirane brigade iz Pančeva. Ove su jedinice s ostalim postrojbama JNA na prostoru Banovine i Korduna 23. rujna 1991. ušle u sastav novoosnovane Prve operativne grupe (OG-1). Komandi OG-1 od 19. listopada 1991. bile su podčinjene i sve vojne jedinice lokalnih Srba, koje su se dotad nalazile pod zapovjedništvom Zonskog štaba TO Banije i Korduna. Vidi MARIJAN 2008: 302; GAJDEK 2008: 325. 
malobrojne i slabo naoružane pripadnike hrvatskih postrojbi na povlačenje. ${ }^{74} \mathrm{Pad}$ strateški značajnog Gornjeg Viduševca pritom je doveo do sloma hrvatske obrane u ovom dijelu Banovine te su glinski ,teritorijalci“ ubrzo izbili na Kupu nedaleko od Pokupskog, istodobno stavivši pod nadzor bitnu prometnicu Glina - Petrinja. ${ }^{75}$ Na taj je način okupirano čitavo etnički homogeno područje između Gline i Kupe, nastanjeno isključivo hrvatskim stanovništvom, koje je najvećim dijelom otišlo u izgnanstvo, dok je dio naknadno smaknut. Ujedno je zauzet i kompletan teritorij prijeratne glinske općine.

Hrvatsko se vojno rukovodstvo, međutim, nije mirilo s novonastalom situacijom, planirajući nova napadna djelovanja na ovom bojištu. Tako su pripadnici 153. velikogoričke brigade Hrvatske vojske (HV) 28. listopada 1991. forsirali Kupu kod Pokupskog, utvrdivši mostobran na njezinoj desnoj obali. ${ }^{76}$ Ratno je predsjedništvo Općine Glina, rukovodeći se pritom i prethodnom odlukom Vlade SAO Krajine od 26. listopada 1991. o provedbi mobilizacije, istoga dana uputilo ,javni proglas“, na temelju kojega su sve muške osobe od 18 do 55 godina s područja glinske općine pozvane da se u roku od 24 sata jave najbližoj Komandi ili Štabu TO „radi mobilizacije u jedinice TO“.77 Odaziv na „proglas“, unatoč ozbiljnosti situacije, bio je iznenađujuće slab. Probleme glede provođenja mobilizacije pritom nije mogla umanjiti ni činjenica da su se hrvatski vojnici, suočeni s otporom srpskih snaga i nedovoljnom potporom ostalih postrojbi HV-a, već 1 . studenog 1991. povukli na početne položaje na lijevoj obali Kupe. ${ }^{78}$

Komandant 1. glinske brigade TO, potpukovnik Marko Vrcelj (koji je komandu nad jedinicom preuzeo u studenom 1991.), svjedoči kako je dio boraca s fronta bio duboko ojađen izbjegavanjem vojne obveze dijela vlastitih sumještana, žaleći se da je Glina „puna nemobilisanih i paradera u uniformama“. ${ }^{79}$ Glinsko je vodstvo SDS-a Krajine, nadalje, iznimno žestoko napadalo profesionalne oficire JNA, nazivajući ih, bez racionalnih argumenata, ,izdajicama“" srpskog naroda, a sa sumnjom se gledalo i na djelovanje pojedinih armijskih jedinica koje su bile smještene na širem području općine. ${ }^{80}$

Imajući u vidu potonje, ne treba se čuditi što su lokalni Srbi nedovoljno spremni dočekali otpočinjanje hrvatske napadne operacije „Vihor“ 12. prosinca

\footnotetext{
74 Žestoki okršaji na Baniji. Politika (Beograd), 1. X. 1991., 1; Teritorijalci osvojili selo Gornji Viduševac. Politika (Beograd), 1. X. 1991., 9.

75 GAJDEK 2008: 193; GAŠLJEVIĆ TOMIĆ 2010: 545; BOŽIĆ I GORŠETA 2002: 130; Oslobođena teritorija sve veća. Politika (Beograd), 3. X. 1991., 7.

76 BOŽIĆ I GORŠETA 2002: 180-205.

77 SFRJ, SAO Krajina, SO Glina, Ratno predsjedništvo, br. 552/91., 28. X. 1991.; Bilten Ratnog predsjedništva i Štaba TO općine Glina (Glina), 11. XI. 1991., 3.

78 BOŽIĆ I GORŠETA 2002: 200.

79 VRCELJ 2002: 24.

80 Isto: 26.
} 
1991. Toga su dana, naime, pripadnici HV-a poduzeli forsiranje Kupe kod mjesta Šišinec, namjeravajući razbiti srpske jedinice i stvoriti preduvjete za eventualno oslobađanje Gline i susjednog teritorija Banovine. Operacija je, međutim, uslijed otpora srpskih snaga, koje su nakon početnih gubitaka organizirale protuudar, te nevoljkosti dijela hrvatskih postrojbi da prijeđu rijeku sukladno s usvojenim planom bojevih djelovanja, ubrzo propala. Postrojbe su HV-a pri tome pretrpjele znatne gubitke u ljudstvu i tehnici, dok su glinski ,teritorijalci“" osobito nastradali u mjestu Gračanici, gdje ih je, u sukobu s hrvatskim snagama, čak devetnaestero poginulo (uz jednog ,teritorijalca“, koji je pritom nestao). ${ }^{81}$

Pogrebna ceremonija za ,žrtve Gračanice“, koja je 19. prosinca održana ispred Spomen-doma u centru Gline, protekla je, očekivano, u dramatičnim tonovima. Tako je kapetan Mile Letica, uime općinskog Štaba TO, istaknuo kako se „ta ustaška gamad (odnosno hrvatski vojnici), ti drogeraši, histeričari, opijeni mržnjom prema svemu što miriše na srpsko“, nisu „odrekli Starčevićeve i Pavelićeve ideologije“ te kako ,njihova iživljavanja na svemu što je srpsko, graniče sa zvjerstvima najgoreg oblika“, zaključivši kako se ne radi o ljudima, već „Zvijerima“ i to ,najstrašnijih vrsta“. 82

Zabrinutost vodstva lokalnih Srba kako će hrvatske postrojbe nakon propasti operacije „Vihor“ ponovno pokušati napasti teritorij Općine Glina nije se, međutim, pokazala opravdanom. Službeni je Zagreb, naime, uslijed teškog unutarnjeg stanja u kojemu se nalazila zemlja i njezina nesređenog vanjskopolitičkog statusa, 2. siječnja 1992. u Sarajevu pristao potpisati sporazum o bezuvjetnom prekidu vatre u Hrvatskoj, čime su stvoreni osnovni preduvjeti za dolazak Zaštitnih snaga Ujedinjenih naroda, sukladno s prihvaćenim mirovnim planom Cyrusa Vancea ${ }^{83}$ $\mathrm{Na}$ taj su način privremeno okončana borbena djelovanja na tlu glinske općine, a mjesni Srbi mogli su se posvetiti daljnjoj konsolidaciji tamošnje civilne vlasti.

\section{Stanje javne sigurnosti na području Općine Glina u 1991. godini}

Začeci i razvoj međunacionalnih trvenja tijekom 1990. pridonijeli su značajnom padu razine javne sigurnosti u glinskoj općini. Sve napetiji hrvatsko-srpski odnosi ubrzo su rezultirali teško podnošljivim stanjem ,ni rata ni mira“, koje je zavladalo na tom prostoru, kulminiravši izbijanjem lokalnih oružanih sukoba u drugoj polovini lipnja 1991.

\footnotetext{
81 GAJDEK 2008: 210-214; VRCELJ 2002: 33-45; ŠPELETIĆ 2011: 28-34; BOŽIĆ I GORŠETA 2002: 28-31; TARBUK 2009: 207-208; Žestoke borbe uz Kupu. Politika (Beograd), 14. XII. 1991., 8; prema svjedočenju srpskih izvora, većina poginulih „teritorijalaca“ iz Gračanice prije smrti bila je zarobljena te je pritom mučena i zlostavljana.

82 Oproštaj od palih drugova. Bilten Ratnog predsjedništva i Štaba TO općine Glina (Glina), siječanj 1992., 10-12; VRCELJ 2002: 42.

83 SEKULIĆ 1996: 25.
} 
$\mathrm{Na}$ teritoriju općine, koji se nalazio pod srpskim nadzorom, $\mathrm{u}$ međuvremenu se pristupilo ustrojavanju organa unutarnjih poslova pod ingerencijom kninskog SUP-a SAO Krajine. Jezgru Milicije Krajine u ovom su kraju isprva, uz bivše pripadnike MUP-a Republike Hrvatske srpske nacionalnosti, koji su se pridružili srpskoj pobuni (među kojima valja istaknuti djelatnike policijske postaje u Glini, koji su nakon 26. lipnja 1991. prešli na srpsku stranu), trebali činiti lokalni mladići, koji su tijekom proljeća 1991. prošli specijalnu policijsku obuku u Golubiću nedaleko od Knina. ${ }^{84}$ U Glini je, nakon konačnog protjerivanja hrvatskih policajaca iz mjesta krajem srpnja 1991., osnovana Stanica javne bezbjednosti (SJB) Glina, na čelu s Dušanom Momčilovićem, koja je do kraja listopada iste godine, zbog velikih oštećenja koja je zgrada lokalne policijske postaje pretrpjela tijekom dotadašnjih sukoba, bila smještena u glinskom Vatrogasnom domu, da bi se potom vratila na nekadašnju lokaciju. ${ }^{85}$ Vodstvo je glinske općine pak, nakon prvih borbi u gradu, nastojeći spriječiti sve prisutnije bezakonje, ali i dodatno učvrstiti vlast, izdalo naredbu kojom se novoosnovanim policijskim organima nalagalo da ,uhapse svaku osobu ili grupu ljudi koji su se organizirali radi vršenja krađa i protupravnog prisvajanja privatne i društvene imovine“" ${ }^{86}$

Iako je politika SDS-a Krajine u osnovi bila izrazito protuhrvatska, njegovi su glinski čelnici početkom ljeta 1991. ipak vodili računa o onim Hrvatima koji su, unatoč izbijanju oružanih sukoba, ostali živjeti u svojim mjestima. Tako je 17. srpnja 1991. održan sastanak vodstva Općine Glina s predsjednicima mjesnih zajednica hrvatskih sela Maje, Prijeke, Dolnjaka i Joševice, a tom je prigodom naglašeno kako je ,ustanak banijskih Srba usmjeren protiv hrvatskog vrhovništva i ustaškog dijela hrvatskog naroda", a ne protiv svih Hrvata. ${ }^{87}$

Uspješna ofenziva glinskih „teritorijalaca“ i JNA na dio općine, koji se dotad nalazio pod nadzorom legalnih vlasti, početkom je listopada 1991. glinskom općinskom vodstvu uzrokovala nove sigurnosne probleme. Na osvojenom je teritoriju, naime, došlo do masovne pljačke hrvatske imovine, paleža, ali i zlostavljanja i ubojstava mjesnih Hrvata. Ratno je izvršno vijeće općine, kako bi tome stalo na kraj, 15. listopada donijelo „Rješenje o stvarima i sredstvima koja se tretiraju kao ratni plijen“, kojim je određeno da se sva takva sredstva ,uzimaju pod zaštitu SO Glina i postaju društveno vlasništvo“, a brigu o njihovu fizičkom osiguranju na

84 Vidi: Hrvatski informativni centar, A 301-30, VP T-7916 Glina, 22. rujna 1992. http:// www. hic.hr/domov-rat07.htm. (posjet 20. 3. 2015); PANDŽA ORKAN 2012: 13-37.

85 Hrvatski memorijalno-dokumentacijski centar Domovinskog rata, Neraspoređeno gradivo, kut. 1071/1, Izvještaj o radu Stanice javne bezbednosti Glina od 26. 06. - 15. 12. 1991. godine, 31. prosinca 1991. (Glina), 9. VII. 1991., 7.

87 Tragična smrt. Bilten Ratnog predsjedništva i Štaba TO općine Glina (Glina), kolovoz 1991., 19. 
sebe preuzima glinski općinski Štab TO. Spomenutim je aktom, nadalje, odlučeno i kako se otuđena sredstva mogu davati u najam pojedinim pravnim i fizičkim osobama, o čemu je trebala odlučivati naknadno formirana „Komisija za ratni plijen“" ${ }^{88}$ Ta je Komisija, po svemu sudeći, u narednim mjesecima imala dosta posla, pa je, primjerice, 22. studenog odobrila izvjesnom Simi Vučetiću iz Gline da iz skladišta tvrtke „Obnova“, u kojemu je bila pohranjena roba koja se smatrala ratnim plijenom, podigne, ,peć na kruto gorivo, sofu, zamrzivač, dva madraca za krevet, stol, šest stolica, posteljinu i tepih“, koje je trebao „,̌uvati“ te ih, ukoliko Komisija to zatraži, vratiti ,u ispravnom stanju“ ${ }^{89}$ Početkom prosinca iste godine dopušteno je, pak, Stojanu Rudanu iz Gline da iz skladišta uzme ,veš-mašinu, sudoper, štednjak i bojler za kuhinju“. Rudan je, u zamolbi Komisiji, naveo kako je izbjeglica iz sela Gornje Taborište te da su mu hrvatski vojnici prethodno „sve opljačkali“".90

Općinsko Ratno izvršno vijeće 15. je listopada usvojilo i „Pravilnik o privremenoj dodjeli mobiliziranih kuća i stanova na području opštine Glina“, na temelju kojega se određivalo kako pravo prvenstva pri rješavanju stambenog pitanja imaju građani, čije su kuće, odnosno stanovi „uništeni neprijateljskim djelovanjem“, zatim ,izbjeglice s područja Republike Hrvatske“ te deficitarni kadrovi, poput oficira JNA i liječnika. ${ }^{91}$ Zapovjednik je glinske brigade TO Marko Vrcelj, unatoč tome, krajem 1991. s ogorčenjem konstatirao kako najveći dio oficira iz njegove jedinice, zbog nemogućnosti osiguranja adekvatnog stambenog prostora, spava u Komandi brigade, što je ocijenio posve nedopustivim. ${ }^{92}$ Manjku je smještajnih kapaciteta u samome gradu Glini, bez sumnje, pridonijelo i namjerno uništavanje objekata, čiji su prijeratni vlasnici, hrvatske nacionalnosti, izbjegli iz mjesta nakon otpočinjanja tamošnjih oružanih sukoba u lipnju, odnosno srpnju 1991. Tako se u izvješću glinske jedinice , protiv-požarne zaštite“ iz prosinca 1991. navodi kako je prilikom obilaska mjesta evidentirano čak 85 zapaljenih kuća (većina hrvatskih vlasnika), uz 53 kuće, koje su bile toliko oštećene da nisu bile pogodne za stanovanje, a od kojih je tek manji dio stradao u izravnim borbenim djelovanjima. ${ }^{93}$

\footnotetext{
88 Rješenje o stvarima i sredstvima koja se tretiraju kao ratni plijen, SFRJ, SAO Krajina, SO Glina, Ratno izvršno vijeće, br. 345/91.; Bilten Ratnog predsjedništva i Štaba TO općine Glina (Glina), 15. X. 1991., 35-36.

89 Hrvatski memorijalno-dokumentacijski centar Domovinskog rata, SO Glina, kut. 2, SFRJ, SAO Krajina, SO Glina, Ratno izvršno vijeće, Komisija za ratni plijen, br. 878/91., 22. studenog 1991.

90 Hrvatski memorijalno-dokumentacijski centar Domovinskog rata, SO Glina, kut. 3, SFRJ, SAO Krajina, SO Glina, Ratno izvršno vijeće, Komisija za ratni plijen, br. 1062/91., 13. prosinca 1991.

91 Pravilnik o privremenoj dodjeli mobiliziranih kuća i stanova na području opštine Glina, SFRJ, SAO Krajina, SO Glina, Ratno izvršno vijeće, br. 387/91.; Bilten Ratnog predsjedništva i Štaba TO općine Glina (Glina), 15. X. 1991., 16-18. 
Čelništvo Općine Glina u međuvremenu je donijelo odluku o prelasku svih poduzeća na području općine na rad u ratnim uvjetima, pri čemu je određeno kako „sve za rad sposobne muške i ženske osobe“, koje nisu angažirane u jedinicama TO, podliježu radnoj obvezi ${ }^{94}$ Ratno je predsjedništvo općine naredilo glinskom Štabu TO i djelatnicima SJB-a Glina da, unatoč tome što je početak nastave u tamošnjim školama zbog sigurnosnih razloga odgođen na neodređeno vrijeme, imaju osigurati dežurstva i „danonoćno osiguranje“ obrazovnih objekata na području općine. ${ }^{95}$ U prosincu 1991. je, pak, uslijed činjenice da se u lokalnim ugostiteljskim objektima konzumiralo mnogo alkohola, pri čemu je ondje dolazilo do incidenata vezanih uz neovlašteno korištenje vatrenim oružjem, kao i do fizičkih obračuna, usvojena odluka o „zatvaranju svih ugostiteljskih radnji na području SO Glina“ do daljnjega, od čega je bio izuzet samo glinski hotel „Kasina“.96

Međutim, stanje je javne sigurnosti na teritoriju glinske općine, neovisno o poduzetim mjerama, postajalo sve lošijim. Ratno je predsjedništvo s tim u vezi svim predsjednicima mjesnih zajednica u općinskom sastavu naložilo da organiziraju vlast „u skladu s ratnim uvjetima“, imajući u vidu poglavito opskrbljivanje ogrjevom i hranom izbjeglica u svojim mjestima, organiziranje berbe kukuruza, organiziranje mjesnih straža te izradu planova potrošnje goriva, nužnog za provođenje jesenske sjetve. Zanimljivo je kako se od spomenutih dužnosnika tražilo i da načine ,popis ukradene i opljačkane robe“ na području pod vlastitim nadzorom i dostave ga „nadležnim organima““.97

Potonje je bilo nužno, budući da se pljačkanje, posebice imovine protjeranih Hrvata, nemilice nastavljalo. Tako je, primjerice, sredinom studenog 1991. u Glini provaljeno u obiteljsku kuću izbjeglog Hrvata Ivana Kreštalice, a tom su prilikom otuđeni TV-uređaj, videorekorder i kamera. ${ }^{98} \mathrm{Nadalje}$, početkom prosinca iste godine nepoznati su počinitelji u selu Gornji Viduševac ukrali napuštenu kamionsku prikolicu..$^{99}$ Dana 22. prosinca 1991., prilikom obilaska sela Joševica, Dolnjaci i

93 Hrvatski memorijalno-dokumentacijski centar Domovinskog rata, SO Glina, kut. 2, Izvještaj Protiv-požarne zaštite Mjesne zajednice Glina, 5. prosinca 1991.

94 Odluka o načinu rada i djelovanja privrednih i vanprivrednih subjekata na području opštine Glina u ratnim uslovima, SFRJ, SAO Krajina, SO Glina, Ratno izvršno vijeće, br. 1006/91., 28. studenog 1991.; Bilten Ratnog predsjedništva i Štaba TO općine Glina (Glina), br. 5, siječanj 1992., 24-25.

95 SFRJ, SAO Krajina, SO Glina, Ratno predsjedništvo, br. 469/91., 16. listopada 1991.; Bilten Ratnog predsjednišstva i Štaba TO općine Glina (Glina), br. 4, 11. XI. 1991., 39.

SFRJ, SAO Krajina, SO Glina, Ratno predsjedništvo, br. 1187/91., 20. prosinca 1991.; Bilten Ratnog predsjedništva i Štaba TO općine Glina (Glina), br. 5, siječanj 1992., 45.

97 SFRJ, SAO Krajina, SO Glina, Ratno predsjedništvo, br. 595/91.; Bilten Ratnog predsjedništva i Štaba TO općine Glina (Glina), 27. X. 1991., 21.

98 Hrvatski memorijalno-dokumentacijski centar Domovinskog rata, SO Glina, kut. 5, SJB Glina, Radni nalog broj 480, 28. studenog 1991.

99 Hrvatski memorijalno-dokumentacijski centar Domovinskog rata, SO Glina, kut. 5, SJB Glina, Radni nalog broj 587, 4. prosinca 1991. 
Prijeka, patrola SJB-a Glina uhitila je dvojicu civila srpske nacionalnosti iz mjesta Balinac, koji su otuđivali imovinu iz tamošnjih napuštenih hrvatskih kuća. ${ }^{100}$ Pljačke, dakako, nisu bili pošteđeni ni vlasnici imovine srpske nacionalnosti. Tako je u studenom 1991. provaljeno u obiteljsku kuću u Glini, čiji se vlasnik, Srbin, nalazio na privremenom radu u Njemačkoj. ${ }^{101}$

Preostalo je hrvatsko stanovništvo glinske općine, s druge strane, bilo izravno ugroženo, pri čemu mu je osobita opasnost prijetila od pripadnika nekolicine lokalnih vojnih skupina, koje su, iako pod formalnim zapovjedništvom općinskog Štaba TO Glina, bile uvelike neovisne te su se bavile raznim oblicima kriminala. Među njima svakako valja izdvojiti skupinu pod vodstvom Siniše Martića-Šilta, čiju je jezgru činilo 20-ak civila iz Gline i okolice, koji su u travnju 1991. završili specijalni policijski tečaj SUP-a SAO Krajine u Golubiću kod Knina. Nakon sudjelovanja u napadu na glinsku policijsku postaju 26. lipnja iste godine i pogibije svog člana Dragiše Stefanovića, skupina je promijenila naziv u „Gerilski odred Dragiša Stefanovićc", da bi se u narednom razdoblju, po vođi Siniši Martiću, prozvali „Šiltovima“. ${ }^{102}$ Na području Općine Glina u drugoj polovini 1991. djelovala je i „Izviđačko-diverzantska grupa Jose Kovačevića“, koja se također bavila pljačkom i maltretiranjem mjesnih Hrvata. ${ }^{103}$

Glinski Hrvati, dakako, nisu mogli očekivati pomoć ni od novoustrojenih policijskih organa SJB-a Glina, koji su ih propustili adekvatno zaštititi. Njihovu je stradanju usto svakako pridonijela i politika lokalnog SDS-a Krajine, koji je s vremenom zauzimao sve radikalniji stav glede mogućnosti hrvatsko-srpskog suživota u budućnosti, u konačnici je posve otklonivši. Kao rezultat navedenog, uslijedili su masovni zločini. Tako je, primjerice, 20. rujna 1991. iz glinskog zatvora odvedeno četvero hrvatskih civila, koji su zatim smaknuti na brdu Pogledić iznad Gline. ${ }^{104}$ U Glinskom Novom Selu, nakon okupacije početkom listopada iste godine, ubijene su 33 osobe hrvatske nacionalnosti, koje su odbile napustiti vlastite domove $^{105}$, dok je petnaestero Hrvata, među kojima i troje djece, likvidirano 11. prosinca 1991. u naselju Gornje Jame. ${ }^{106}$

100 Hrvatski memorijalno-dokumentacijski centar Domovinskog rata, SO Glina, kut. 5, SJB Glina, Radni nalog broj 906, 23. prosinca 1991.

101 Hrvatski memorijalno-dokumentacijski centar Domovinskog rata, SO Glina, kut. 5, SJB Glina, Radni nalog, 22. studenog 1991.

102 Vidi: Hrvatski informativni centar, A 301-30, VP T-7916 Glina, 22. rujna 1992. http:// www. hic.hr/domov-rat07.htm. (posjet 20. 3. 2015); PANDŽA ORKAN 2012: 13-37.

103 Vidi: Hrvatski informativni centar, A 301-30, VP T-7916 Glina, 22. rujna 1992. http:// www. hic.hr/domov-rat07.htm. (posjet 20. 3. 2015).

104 Vidi:Zločin na brdu Pogledić. http://www.documenta.hr/hr/zločin_na_brdu_pogledić_kraj_gline.html. (posjet 26. 6. 2014). Prvooptuženi za ovaj zločin, Rade Miljević iz Gline, nakon dva je ponovljena suđenja (2006./2007. i 2008.) 2014. definitivno oslobođen krivnje prema svim točkama optužnice, a sam je zločin do današnjeg dana ostao nerasvijetljen.

105 KRPAN 2007: 637.

106 Vidi: Dan kad su anđeli plakali. http://www.dragovoljac.com/forum/index.php?topic=420.0;wap2. (posjet 22. 9. 2015). 
U mjestu Joševica 16. prosinca 1991. nepoznati su počinitelji usmrtili 21 civilnu osobu hrvatske nacionalnosti. ${ }^{107}$ Iako se pretpostavljalo kako su zločin izvršili pripadnici srpskih jedinica, kao odmazdu za smrt glinskih boraca, stradalih tijekom trajanja operacije „Vihor“" u Gračanici, dr. Jović je u priopćenju, koje je objavio uime Općine Glina, za ubojstva okrivio „ubačenu hrvatsku diverzantsko-terorističku grupu s područja Cazinske krajine", istaknuvši da se tim činom pokušalo „kompromitirati““ srpski narod. ${ }^{108}$ Potpukovnik je Vrcelj naknadno, osvrnuvši se na taj slučaj, istaknuo vlastito zgražanje nad njime, posebice stoga što se radilo o selu čiji su stanovnici izrazili pokornost okupacijskim vlastima SAO Krajine, a u Drugom svjetskom ratu na partizanskoj su se strani borili rame uz rame s mjesnim Srbima. Pri tome se, posve opravdano, zapitao: „Kome su to od Hrvata koji su ostali da žive sa nama, Srbima, ti isti Srbi garantovali da neko u toku noći neće doći da ih pokolje...? Kome je to ova nova država, u kojoj su ostali da žive, garantovala sigurnost i bezbednost?"“109

Vrcelj se nedugo zatim osobno angažirao na izvlačenju Hrvata iz okolnih sela u Glinu, predavši ih lokalnom Crvenom križu. ${ }^{110}$ Većina tih osoba potom je otišla u progonstvo, dok ih je dio likvidiran. Zločini nad malobrojnim preostalim hrvatskim stanovništvom glinske općine nastavili su se, međutim, i u idućem razdoblju.

\section{Zaključak}

Obrađujući ovu složenu problematiku, nameće se nekoliko zaključaka. Kao prvo, valja konstatirati kako su zbivanja iz ranih 1990-ih, počevši od povratka višestranačja pa do otpočinjanja te širenja međunacionalnih sukoba, u kratkom vremenu dovela do temeljitog urušavanja socijalnih, ekonomskih, kulturnih, međuetničkih i inih veza i odnosa, koji su se u glinskoj općini izgrađivali desetljećima. Za to prvenstvenu odgovornost snosi tadašnje političko rukovodstvo krajinskih Srba, koje je, podupirući velikosrpsku politiku Slobodana Miloševića i negiravši volju većinskog hrvatskog naroda o izdvajanju iz sastava SFRJ i formiranju vlastite nacionalne države, svoje sunarodnjake gurnulo u rat, u kojemu su naposljetku teško vojno poraženi. Čelnici glinskog SDS-a (odnosno SDS-a Krajine) pritom su uglavnom vjerno slijedili naputke iz Knina, otklanjajući ikakvu mogućnost eventualnog suživota s mjesnim Hrvatima u budućnosti. Na taj su način uvelike pridonijeli naknadnom masovnom odlasku srpskog stanovništva u izgnanstvo.

$\overline{107}$ Hrvatski memorijalno-dokumentacijski centar Domovinskog rata, Neraspoređeno gradivo, SFRJ, SAO Krajina, SUP Knin, SJB Glina, br. KU-14/91., Krivična prijava protiv nepoznatog učinioca krivičnog djela, 28. prosinca 1991.; PANDŽA ORKAN 2012: 77-85.

BARIĆ 2005: 374-375.

109 VRCELJ 2002: 45.

$110 \mathrm{Na}$ istome mjestu. 
Nadalje, područje Općine Glina doživjelo je znatna razaranja tijekom ratnih zbivanja 1991., pri čemu je za tamošnje Srbe nepovoljnu okolnost predstavljala činjenica da se linija razgraničenja s hrvatskim postrojbama, sve do sloma RSK 1995., nalazila u relativnoj blizini same Gline.

Stanje javne sigurnosti bilo je, s druge strane, veoma loše. Malobrojne se preostale Hrvate, sukladno s time, maltretiralo i zlostavljalo prema nacionalnoj osnovi, dok im se imovina otuđivala. Dio stanovnika glinske općine hrvatske nacionalnosti, civila i mahom starijih osoba smaknule su srpske postrojbe, pri čemu ih lokalne krajinske vlasti nisu zaštitile. Mjesni su Srbi, međutim, ubrzo i sami iskusili sve nedaće nefunkcioniranja pravne države, promatrajući kako se dotadašnje vrijednosti, a poglavito prijeratna, ipak solidna financijska i socijalna stabilnost, ruše iz temelja, te društvo ponire u posvemašnju besperspektivnost $\mathrm{i}$ anarhiju.

Sagledavanjem svih dostupnih činjenica postaje bjelodanim kako je neuspio pokušaj provedbe velikosrpskog projekta nanio golemu i teško mjerljivu štetu kako hrvatskom, tako i srpskom stanovništvu ovoga kraja, od koje se sama Glina, kao ni Banovina općenito, ni dan-danas, iako je od okončanja rata prošlo punih dvadeset godina, nisu ni izbliza oporavile.

\section{Bibliografija}

\section{Neobjavljeni izvori}

Arhiv Policijske uprave sisačko-moslavačke

Hrvatski memorijalno-dokumentacijski centar Domovinskog rata, fond Srpska demokratska stranka

Hrvatski memorijalno-dokumentacijski centar Domovinskog rata, fond Skupština općine Glina

Hrvatski memorijalno-dokumentacijski centar Domovinskog rata, fond 4, Vlada SAO Krajine/RSK

Nadbiskupski arhiv u Zagrebu, fond Nadbiskupski duhovni stol, Glina 1955.-1995.

\section{Periodika}

Bilten Općinske organizacije SKH Glina (Glina)

Bilten Ratnog predsjedništva i Štaba TO općine Glina (Glina)

Borba (Beograd)

Glasnik Hrvatske demokratske zajednice (Zagreb)

Jedinstvo (Sisak)

Narodna armija (Beograd) 
Politika (Beograd)

Srpski glas (Topusko)

Večernji list (Zagreb)

\section{Objavljeni izvori}

PANDŽA ORKAN, Ivica (ur.). 2012. Vojska Krajine u Pounju i na Banovini (zapisi komšija). Sisak: Agencija za istraživanje i dokumentaciju ratnih sukoba.

PAUKOVIĆ, Davor (ur.). 2005. Uspon i pad Republike Srpske Krajine: dokumenti. Zagreb: Centar za politološka istraživanja.

RUPIĆ, Mate (ur.). 2007a. Republika Hrvatska i Domovinski rat 1990.-1995., Dokumenti 1990.-1991. Knjiga 1. Zagreb: Hrvatski memorijalno-dokumentacijski centar Domovinskog rata.

RUPIĆ, Mate (ur.). 2007b. Republika Hrvatska i Domovinski rat 1990.-1995., Dokumenti institucija pobunjenih Srba u Republici Hrvatskoj (1990.-1991.). Knjiga 2. ZagrebSlavonski Brod: Hrvatski memorijalno-dokumentacijski centar Domovinskog rata, Hrvatski institut za povijest, Podružnica za povijest Slavonije, Baranje i Srijema.

\section{Literatura}

BARIĆ, Nikica. 2005. Srpska pobuna u Hrvatskoj 1990.-1995. Zagreb: Golden marketing, Tehnička knjiga.

BILANDŽIĆ, Dušan. 1999. Hrvatska moderna povijest. Zagreb: Golden marketing, Tehnička knjiga.

BOLJKOVAC, Josip. 2009. Istina mora izaći van. Zagreb: Golden marketing, Tehnička knjiga.

BOŽIĆ, Aleksandar, Damir GORŠETA. 2002. 153. velikogorička brigada HV. Velika Gorica: Turopoljski glasnik.

CRKVENČIĆ-BOJIĆ, Jasna (ur.). 1998. Narodnosni $i$ vjerski sastav stanovništva Hrvatske 1880.-1991. po naseljima. Knjiga 2. Zagreb: Državni zavod za statistiku Republike Hrvatske.

DAKIĆ, Mile. 1994. Srpska Krajina; istorijski temelji i nastanak. Knin: Iskra.

GAJDEK, Đuro. 2008. Petrinjska bojišnica 1991.-1995. Petrinja: Grad Petrinja.

GAŠLJEVIĆ TOMIĆ, Katica. 2010. Selo i župa Viduševac. Zagreb: Ibis grafika.

GOLDSTEIN, Ivo. 2008. Hrvatska 1918.-2008. Zagreb: EPH liber.

GRDEŠIĆ, Ivan, Mirjana KASAPOVIĆ, Ivan ŠIBER, Nenad ZAKOŠEK. 1991. Hrvatska u izborima '90. Zagreb: Naprijed.

KNEŽEVIĆ, Domagoj. 2011. Srpska demokratska stranka od osnivanja do konstituiranja prvog višestranačkog Sabora. Časopis za suvremenu povijest 43/1: 7-24.

KRPAN, Vladimir (ur.). 2007. Novo Selo Glinsko. Novo Selo Glinsko-Petrinja: Zavičajni klub Novo Selo Glinsko, Matica hrvatska Petrinja.

MARIJAN, Davor. 2008. Slom Titove armije. Zagreb: Golden marketing, Tehnička knjiga. 
MATKOVIĆ, Hrvoje. 2006. Na vrelima hrvatske povijesti. Zagreb: Golden marketing, Tehnička knjiga.

MESIĆ, Stjepan. 1992. Kako smo srušili Jugoslaviju. Zagreb: Globus International.

NAZOR, Ante. 2007. Počeci suvremene hrvatske države (kronologija procesa osamostaljenja Republike Hrvatske: od Memoranduma SANU 1986. do proglašenja neovisnosti 8. listopada 1991.). Zagreb: Hrvatski memorijalno-dokumentacijski centar Domovinskog rata.

NOVAKOVIĆ, Kosta. 2009. Srpska Krajina; usponi, padovi, uzdizanja. Knin-Beograd: Srpsko kulturno društvo Zora.

PASPALJ, Mile. 1996. Album iz Krajine. Sarajevo: Javnost.

PETROVIĆ, Ilija. 1996. Slavonija, Baranja i Zapadni Srem; od Vijeća do Republike. Novi Sad: Cvetnik.

RADULOVIĆ, Srđan. 1996. Sudbina Krajine. Beograd: Dan graf.

RUNTIĆ, Davor. 2003. Prvi hrvatski redarstvenik. Zagreb: Udruga Prvi hrvatski redarstvenik.

SEKULIĆ, Milisav. 2000. Knin je pao u Beogradu. Bad Vilbel: Nidda Verlag.

ŠPELETIĆ, Tomo Krešo (ur.). 2011. 102. brigada Hrvatske vojske Novi Zagreb. Zagreb: Klub veterana 102 . brigade HV.

TARBUK, Slobodan. 2009. Rat na Baniji 1991.-1995. Beograd: Srpsko kulturno društvo Zora.

VRCELJ, Marko. 2002. Rat za Srpsku Krajinu 1991.-1995. Beograd: Srpsko kulturno društvo Zora.

ŽUNEC, Ozren. 2007. Goli život, Socijetalne dimenzije pobune Srba u Hrvatskoj. Knjiga 1. Zagreb: Demetra.

\section{Elektronička dokumentacija}

Hrvatski informativni centar, A 301-30, VP T-7916 Glina, 22. rujna 1992.

http://www.hic.hr/domov-rat07.htm (posjet 20. 3. 2015).

Zločin na brdu Pogledić. http://www.documenta.hr/hr/zločin_na_brdu_pogledić_kraj_gline.html (posjet 26. 6. 2014).

Dan kad su anđeli plakali.

http://www.dragovoljac.com/forum/index.php?topic=420.0; wap2 (posjet 22. 9. 2015). 


\section{Political and Military-Security Aspect of Events in the Glina District 1990 - 1991}

This paper endeavours to answer a research question from a political and military-security perspective about the development of circumstances in Glina and its area from the return of the multiparty system in 1990 to the outbreak of local armed conflicts and the annexation of the Glina district to Republic of Serbian Krajina in December 1991.

The research is based on the original archives of the Serbian and Croatian provenance kept in the Croatian Memorial Documentation Centre of the Homeland War and Archives of the Archdiocese of Zagreb, as well as the Archives of the Sisačko-moslavačka County in Sisak. The secondary and tertiary historical sources on this issue have also been consulted, such as the 1991 to 1995 publications from the area controlled by the „Krajina“ government (Srpski glas, Bilten Ratnog predsjedništva i Štaba TO Glina), the Republic of Serbia (Politika, Borba, Narodna armija) and the territory of the Republic of Croatia controlled by the legal government (Večernji list). This has been supplemented with the available monographs by both Croatian and Serbian authors about the occurrences in the wartime Croatia of the 1990's, since to the larger or lesser degree they also refer to occurrences in the Glina area.

I believe that by meticulously analysing and mutually comparing all the mentioned sources it is possible to reach a relatively clear image on the outset and culmination of the interethnic conflicts on the observed territory. In spite of this, this paper should be viewed as a mere contribution to the future more complex research of the Homeland war in the Banovina area which, I hope, will be undertaken in the near future.

Keywords: Republic of Croatia, Homeland war, Banovina, Glina, SAO Krajina, RSK, JNA Ključne riječi: Republika Hrvatska, Domovinski rat, Banovina, Glina, SAO Krajina, RSK, JNA

Slaven Ružić slaven.ruzic@centardomovinskograta.hr Hrvatski memorijalno-dokumentacijski centar Domovinskog rata HR-10000 Zagreb, Marulićev trg 21 


\section{FILOZOFSKI FAKULTET SVEUČILIŠTA U ZAGREBU \\ ZAVOD ZA HRVATSKU POVIJEST \\ INSTITUTE OF CROATIAN HISTORY \\ INSTITUT FÜR KROATISCHE GESCHICHTE}
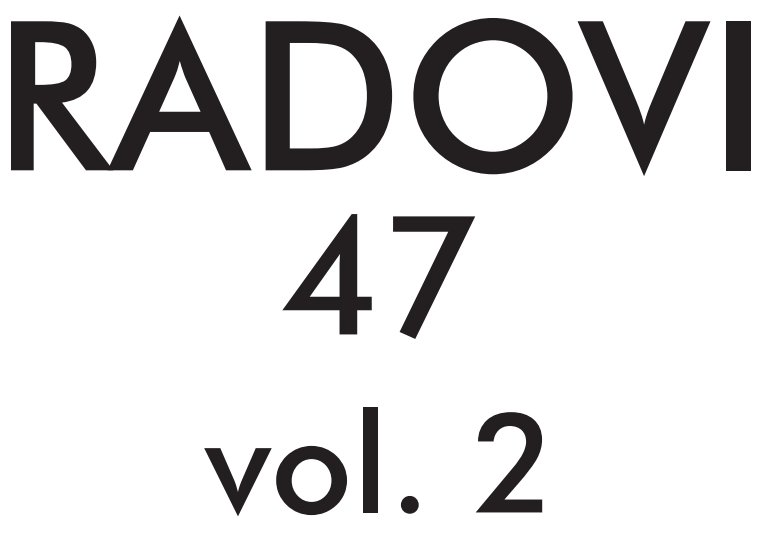

ZAVOD ZA HRVATSKU POVIJEST

FILOZOFSKOGA FAKULTETA SVEUČILIŠTA U ZAGREBU

FF press

ZAGREB 2015. 


\title{
RADOVI ZAVODA ZA HRVATSKU POVIJEST FILOZOFSKOGA FAKULTETA SVEUČILIŠTA U ZAGREBU
}

\author{
Knjiga 47, vol. 2
}

\author{
Izdavač / Publisher \\ Zavod za hrvatsku povijest \\ Filozofskoga fakulteta Sveučilišta u Zagrebu \\ FF-press \\ Za izdavača / For Publisher \\ Vlatko Previšić \\ Glavni urednik / Editor-in-Chief \\ Hrvoje Gračanin \\ Izvršna urednica / Executive Editor \\ Inga Vilogorac Brčić \\ Uredništvo / Editorial Board
}

Bruna Kuntić-Makvić (stara povijest/ancient history), Zrinka Nikolić Jakus (srednji vijek/ medieval history), Hrvoje Petrić (rani novi vijek/early modern history), Željko Holjevac (moderna povijest/modern history), Tvrtko Jakovina (suvremena povijest/contemporary history),

Silvija Pisk (mikrohistorija i zavičajna povijest/microhistory and local history),

Zrinka Blažević (teorija i metodologija povijesti/theory and methodology of history)

Međunarodno uredničko vijeće / International Editorial Council

Denis Alimov (Sankt Peterburg), Živko Andrijašević (Nikšić), Csaba Békés (Budapest), Rajko Bratož (Ljubljana), Snježana Buzov (Columbus, Ohio), Svetlozar Eldarov (Sofija), Toni Filiposki (Skopje), Aleksandar Fotić (Beograd), Vladan Gavrilović (Novi Sad), Alojz Ivanišević (Wien),

Egidio Ivetić (Padova), Husnija Kamberović (Sarajevo), Karl Kaser (Graz),

Irina Ognyanova (Sofija), Géza Pálffy (Budapest), Ioan-Aurel Pop (Cluj),

Nade Proeva (Skopje), Alexios Savvides (Kalamata), Vlada Stanković (Beograd), Ludwig Steindorff (Kiel), Peter Štih (Ljubljana)

Izvršna urednica za tuzemnu i inozemnu razmjenu / Executive Editor for Publications Exchange Kristina Milković

Tajnik uredništva / Editorial Board Assistant
Dejan Zadro

Adresa uredništva/Editorial Board address

Zavod za hrvatsku povijest, Filozofski fakultet Zagreb, Ivana Lučića 3, HR-10 000, Zagreb

Tel. ++385 (0)1 6120 150, 6120 158, faks ++385 (0)1 6156879

Časopis izlazi jedanput godišnje / The Journal is published once a year

Časopis je u digitalnom obliku dostupan na / The Journal in digital form is accessible at Portal znanstvenih časopisa Republike Hrvatske „Hrčak“ http://hrcak.srce.hr/radovi-zhp

Financijska potpora za tisak časopisa / The Journal is published with the support by

Ministarstvo znanosti, obrazovanja i športa Republike Hrvatske

Časopis je indeksiran u sljedećim bazama / The Journal is indexed in the following databases:

Directory of Open Access Journals, EBSCO, SCOPUS, ERIH PLUS 
Naslovna stranica

Iva Mandić

Grafičko oblikovanje i računalni slog

Marko Maraković

Lektura

Samanta Paronić

Tisak

Web2tisak, Zagreb

Naklada

250 primjeraka

Časopis je u digitalnom obliku dostupan na Portalu znanstvenih časopisa Republike Hrvatske ,Hrčak“ http://hrcak.srce.hr/radovi-zhp

The Journal is accessible in digital form at the Hrcak - Portal of scientific journals of Croatia http://hrcak.srce.hr/radovi-zhp 


\section{RADOVI 47}

\section{vol. 2}

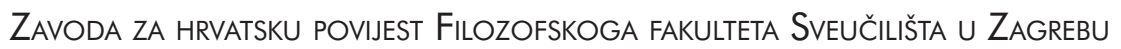

